\title{
STRUCTURING KEY CREDIT RISK PARAMETERS FOR REGULATED ELECTRIC AND GAS UTILITIES UNDER ALTERNATIVE MOODY'S RATING METHODOLOGIES: A CASE STUDY FOR A NATURAL GAS DISTRIBUTION UTILITY
}

\author{
DOI: 10.17261/Pressacademia.2021.1504 \\ PAP- V.14-2021(30)-p.123-215
}

Vahit Ferhan Benli ${ }^{1}$, Feyzullah Yetgin ${ }^{2}$

${ }^{1}$ Istanbul Commerce University, Banking and Finance Department, Istanbul, Turkey. vfbenli@ticaret.edu.tr, ORCID: 0000-0002-0510-7662

${ }^{2}$ Istanbul Commerce University, Banking and Finance Department, Istanbul, Turkey. fyetgin@ticaret.edu.tr, ORCID: 0000-0002-3712-845X

\section{To cite this document}

Benli, V. F., Yetgin, F. (2021). Structuring key credit risk parameters for regulated electric and gas utilities under alternative moody's rating methodologies: a case study for a natural gas distribution utility. PressAcademia Procedia (PAP), 14, 123-125.

Permanent link to this document: http://doi.org/10.17261/Pressacademia.2021.1504

Copyright: Published by PressAcademia and limited licensed re-use rights only.

\section{ABSTRACT}

Purpose- The LNG companies are on the brink of a big energy crisis since the advent of Covid-19. In the forefront of global credit defaults of LNG distribution companies, many economic subjects in this sense may be in need of credit ratings in different contexts. The existence of these variety in "principals inside the LNG game" and in in ratings universe causes somewhat conflicting informational objectives. This metamorphosis in ratings might bridge those informational asymmetries between different players/principals in diverse markets at different geographical arenas with different models. This paper elaborates the relevancy issue of different Moody's rating models in the context of credit risk analysis process of a natural gas distribution company in Turkey.

Methodology- This study relies on case studies namely the Enron case and a case from regulated natural gas distribution company in Turkey. Enron case reveals the actions of CRDs and how the default of Enron would be unmasked by using the market implied Vasicek methodology. As per rating methodology concerns, we will be following Vasicek and also rely our fundamental analysis of credit risks and defaults on the rating models used by CRA's. Therefore, two different rating models of Moody's corporation and Moody's analytics will be used in order to differentiate between the two different approaches which might serve to different informational needs of different users. Such analysis is necessary to understand the "relevancy" issues, as two different model might provide different ratings for the same obligor. Within this understanding, the present study focuses on the analysis and modelling of credit risk in an emerging market for The first model, which is the "Regulated Electric and Gas Rating Methodology of Moody's Investor Services" dated from March the 16th, 2017, is based on a detailed factors grid specified by the key pillars natural gas distribution business. This model's capabilities are contrasted on the grounds of a secondary model designed for emerging markets developed by the sister company of Moody's Investor Services renamed after “Moody's Analytics". The agency based rating model of Moody's Investor Services and the market implied rating methodology which is developed by the Moody's Analytics are used to rate a natural gas distribution company in Turkey. In the light of the relevant findings, it is seen that a single model is not enough to rate a company operating in developing markets. For this reason, it is thought that rating models suitable for the structure of the analysis desired should be selected. This result should be recognized by the regulatory institutions so that the usage of two different models by financial institutions should not give way to a rating arbitrage.

Findings- Enron case highlights the importance of point-in-time rating models over agency based rating models. Within the scope of natural gas distribution company case, care has been given to two different credit risk models of Moody's. The EDF model provided a PD value of $0.65 \%$, which corresponds to Baa3 level in Moody's rating agency terms. When this PD is combined with qualitative factors, a final PD ratio of $0.77 \%$ is attained. This corrected PD corresponds to Ba1 level of rating. Thus, the Company we rated migrates from Investment Grade to Speculative Grade when qualitative factors are considered in the model. In REGU model, the Company is rated with "Ba", which is in "Speculative Grade". It's PD ratio is $1.01 \%$. This result indicates us a severe difference in default probabilities for the same entity. This is consequent and in line with the informational needs of different users and if different models are used respective to their needs. A borrowing entity or an issuer would prefer a PD which is lower and an investor would prefer to be rated with the model, which would provide us a lower rating with higher credit spreads to fulfil the investor needs. We support our decision-making process for extending loans, managing portfolios pricing debt securities when there is little available market insight into a firm's prospects by using the The Moody's "RiskCalc v3.1" model.

Conclusion- It may be concluded that each rating model is developed by rating agencies for different purposes and models used here would belong either to structural or to the statistical agency model. It is also concluded that a firm does not have an absolute correct rating and or default probability within the same period because each rating model uses different criteria and methods, which might be alternative to 
different user needs. EDF credit risk models provide better prediction capabilities of default than its alternative REGU model. Because EDF credit measures are based on market prices they are forward looking and reflect the current position in the credit cycle. They are a timely and reliable measure of credit quality. We need to choose the appropriate rating model to make accurate analysis and minimize risks for providing correct information on different user types and level.

Keywords: Rating, modelling credit risk, risk management, Moody's, natural gas distribution JEL Codes: G32, C51, D81

\section{REFERENCES}

Augar, Ph. (2005). The Greed Merchants. How the Investment Banks played the Free Market Game, Allen Lane.

Bayraktar, A. (2018). Energy Transition in Turkey. In: Turkish Policy Quarterly, 17(3), 19-26.

BDDK (2020). Türk Bankacılık Sektörü Temel Göstergeleri.

Bryce, R. (2002). Pipe Dreams. Greed, Ego and the Death of Enron, The Perseus Book Group.

Crouhy, M., Galai, D., Mark, R. (2000). A Comparative Analysis of Current Credit Risk Models. In: Journal of Banking \& Finance 24.

Cruver, B. (2003). The Unshredded Truth from an Enron Insider: Enron, Anatomy of Greed, Arrow Books.

De Laurentis, G., Maino, R., Molteni, L. (2010). Developing, Validating and Using Internal Ratings, Methodologies and Case Studies, John Wiley.

The Economist (October 16th - 22nd 2021). The Energy Shock, 11.

The Economist ( October 9th - 15th 2021). The Shortage Economy, 11.

Fight, A. (2001). The Ratings Game, John Wiley.

Fox, L. (2003). Enron, The Rise and Fall, John Wiley.

Fusaro, P.C. \& Miller, R.M. (2002). What Went Wrong at Enron, John Wiley.

Glantz, M. (2003). Managing Bank Risk, An Introduction to Broad Base Credit Engineering, Academic Press.

Gilardoni, A. (2008). The World Market for Natural Gas; Implications for Europe, Springer-Verlag Berlin Heidelberg 2008.

Gaillard, N. (2012). A Century of Sovereign Ratings, Springer 2012

Langohr, H.\&Langohr, P. (2008). The Rating Agencies and Their Credit Ratings: What They are, How They Work, And Why They are Relevant, Wiley.

Löffler, G. \& Posch, P. (2007). Credit Risk Modelling, Using Excel und VBA, John Wiley 2007.

Friedman, M. \& Schwartz, A.J. (1963). A Monetary History of the United States 1867-1960, Princeton University Press.

Jaffe, M.A. \& Soligo, R. (2006). Market structure in the new gas economy, Is cartelization possible? In: Victor, D.G./Jaffe, A.M./Hayes M.H. (eds.): Natural Gas and Geopolitics, From 1970 to 2010, Cambridge 2006.

Mallaby, S. (2016). The Man Who Knew: The Life and Times of Alan Greenspan, Penguin Press.

Merton, Robert C. (1974). On the Pricing of Corporate Debt: The Risk Structure of Interest Rates, Journal of Finance 29, pp. 449-70.

Moody's KMV (2003). Modelling Default Risk, Modelling Methodology, December 2003.

Moody's KMV (2004). Moody's KMV Riskcalc 3.1 Model, Next-Generation Technology for Predicting Private Firm Credit Risk, April 2004.

Moody's KMV (2007). EDF implied Ratings, Modelling Methodology, June 2007.

Moody's Investor Services (2009). Moody's Global Infrastructure Finance, Regulated Electric and Gas Utilities, August 2009.

Moody's Analytics (2010): RiskCalc v3.1, Emerging Markets Model, 25 October 2010.

Moody's Investor Service (April 2004). Global Integrated Oil \& Gas Industry, Rating Methodology.

Moody's Investor Service (March 2017). Regulated Electric and Gas Networks, Rating Methodology.

Moody's Investor Service (July 2018). Natural Gas Pipeline, Rating Methodology.

Moody's Investor Service (January 2020). Annual Default Study: Defaults Will Edge Higher. 
Moody's Investor Service (28 January 2021). Default Trends Global: Annual Default Study: Following a sharp rise in 2020, corporate default will drop in 2021

Norbert, G. (2012). A Century of Sovereign Ratings, Springer.

Ong, M.K. (1999). Internal Credit Risk Models. Capital Allocation and Performance Measurements, Risk Books.

Saunders, A.\&Allen, L. (2002). Credit Risk Measurement, New Approaches to Value-at-Risk Paradigms, 2nd ed., Wiley Finance.

Smithson, Ch. (2003). Credit Portfolio Management, John Wiley.

Vasicek, O.A. (22 March 1984). Credit Valuation, White Paper, KMV Corporation. 